\title{
SIMULTANEOUS QUANTIFICATION OF PENTAZOCINE AND NALOXONE BY STABILITY INDICATING REVERSE-PHASE-HIGH-PERFORMANCE LIQUID CHROMATOGRAPHIC METHOD
}

\author{
RAMA KUMAR KANDULA*, RAJA SUNDARARAJAN
}

Department of Pharmaceutical Analysis, Institute of Pharmacy, Gandhi Institute of Technology and Management University, Visakhapatnam, Andhra Pradesh, India. Email: ramakumarkandula@gmail.com

Received: 01 July 2019, Revised and Accepted: 29 July 2019

\section{ABSTRACT}

Objective: The objective of the study was to develope a stability indicating high-performance liquid chromatographic (HPLC) method for simultaneous assay of pentazocine and naloxone in bulk and tablets.

Methods: Pentazocine and naloxone were analyzed on Dionex C18 column using 0.1 $\mathrm{M} \mathrm{K}_{2} \mathrm{HPO}_{4}$ buffer ( $\left.\mathrm{pH} 4.0\right)$ and methanol (60:40, $v / v$ ) as the mobile phase. The concentration of pentazocine and naloxone was quantified by photodiode array detector set at $248 \mathrm{~nm}$. The method was validated in compliance with ICH rules. Pentazocine and naloxone tablet formulation was subjected to forced degradation such as acid, neutral and alkali hydrolysis, oxidation, photo, and thermal degradation.

Results: The method was linear, with $\mathrm{R}^{2}=0.9999$ in the concentration range $100-300 \mu \mathrm{g} / \mathrm{ml}$ for pentazocine and $\mathrm{R}^{2}=0.9995$ in the concentration range $1-3 \mu \mathrm{g} / \mathrm{ml}$ for naloxone. The level of detection and quantification was $0.097 \mu \mathrm{g} / \mathrm{ml}$ and $0.322 \mu \mathrm{g} / \mathrm{ml}$ for pentazocine and $0.0073 \mu \mathrm{g} / \mathrm{ml}$ and $0.0243 \mu \mathrm{g} / \mathrm{ml}$ for naloxone, respectively. The degraded products are resolved well from pentazocine and naloxone with significantly different retention time values. From validation results, it was proved that the method is selective, precise, robust, and accurate for the estimation of pentazocine and naloxone simultaneously.

Conclusion: The developed stability-indicating HPLC method can be applied for quantitative determination of pentazocine and naloxone in tablets.

Keywords: Pentazocine, Naloxone, Synthetic opioids, Degradation, Reverse-phase high-performance liquid chromatographic.

(C) 2019 The Authors. Published by Innovare Academic Sciences Pvt Ltd. This is an open access article under the CC BY license (http://creativecommons. org/licenses/by/4. 0/) DOI: http://dx.doi.org/10.22159/ajpcr.2019.v12i9.34746

\section{INTRODUCTION}

Pentazocine, chemically known as (2RS,6RS,11RS)-6, 11-dimethyl-3(3-methylbut-2-en-1-yl)-1,2,3,4,5,6-hexahydro-2,6-methano-3benzazocin-8-ol (Fig. 1), is an synthetic opioid. It has agonist activity at $\mathrm{k}$ and $\sigma$ opiate receptors and antagonist activity at $\mu$ opiate receptor [1-3]. Pentazocine is used as a pain reliever for moderate to severe pain [3-5].

Naloxone, chemically known as (4R,4aS,7aR,12bS)-4a,9-dihydroxy3-prop-2-enyl-2,4,5,6,7a,13-hexahydro-1H-4,12-methanobenzofuro [3,2-e]isoquinoline-7-one (Fig. 1), is a synthetic $N$-allyl oxymorphone derivative with opiate antagonist activity [6,7]. It has antagonist activity at $\mathrm{k}, \mu$, and $\sigma$ opiate receptors. Naloxone is used in emergency cases to reverse respiratory depression due to overdoses of opioids such as morphine, heroin, and other opioids [8-11]

The fixed-dose combination of pentazocine and naloxone was approved by theFDA[12].The combination ofpentazocineand naloxone is used to reduce pain that is extreme requiring opioid therapy as it may not be tolerated or other pain medications have not worked well enough [13,14]. Pentazocine was quantified in pharmaceutical samples [15-17], human serum [18], human plasma [19-21], human urine [21,22], and whole human blood [22] using visible spectrophotometry [15,16], Thin-layer chromatography [17], high-performance liquid chromatographic (HPLC) [18-20], potentiometry [21], and gas chromatography [22]. Naloxone was quantified in microparticles [23], dosage forms [24], transdermal formulations [25], human plasma [26-28], human urine [28], and human liver microsomes [28] using spectrophotometry [23], HPLC [23-27], and liquid chromatography-mass spectrometry [28].

Untill date, no technique was published regarding the simultaneous estimation of pentazocine and naloxone. The present research therefore focuses on development of reverse-phase HPLC (RP-HPLC) method followed by validation as per the ICH guidelines.

\section{MATERIALS AND METHODS}

\section{Instrumentation}

HPLC analysis of pentazocine and naloxone was performed using Waters HPLC Alliance system (Waters Corporation, USA) equipped with a controller, quaternary pump, degasser, auto sampler, photodiode detector, and column oven. The processing of data was done using empower 2 software.

\section{Materials}

Pentazocine (98\% purity) and naloxone (98\% purity) were procured from Rainbow Pharma Training Lab (Hyderabad, India). The organic solvent (methanol) and chemicals $\left(\mathrm{K}_{2} \mathrm{HPO}_{4}, \mathrm{NaOH}, \mathrm{HCl}, \mathrm{H}_{2} \mathrm{O}_{2}\right.$, and $\mathrm{H}_{2} \mathrm{PO}_{4}$ ) were of HPLC and analytical grade, respectively. Pentazocine and naloxone combination tablets (Lupin Pharmaceuticals, Inc., Baltimore) labeled to contain $50 \mathrm{mg}$ of pentazocine and $0.5 \mathrm{mg}$ of naloxone was obtained from a local pharmacy store (Hyderabad, India).

\section{Chromatography conditions}

The column was a C18 Dionex column $(250 \mathrm{~mm} \times 4.6 \mathrm{~mm}, 5 \mu \mathrm{m}$ particle size; Thermo Fisher Scientific, US). The column temperature was kept at ambient $\left(25^{\circ} \mathrm{C}\right)$. The mobile phase consisted of $\mathrm{K}_{2} \mathrm{HPO}_{4}$ buffer $(0.1 \mathrm{M}$, $\mathrm{pH} 4.0$ units, adjusted with $\left.\mathrm{H}_{2} \mathrm{PO}_{4}\right)$ and methanol $(60: 40, v / v)$. The flow rate and runtime were kept at $1.0 \mathrm{ml} / \mathrm{min}$ and $8 \mathrm{~min}$, respectively. Detection wavelength of $248 \mathrm{~nm}$ was optimized. The mobile phase was used as a diluent in the preparation of solutions.

\section{Standard solutions}

Hundred $\mathrm{mg}$ of pentazocine and $1 \mathrm{mg}$ of naloxone were correctly weighed with microbalance and dissolved in $100 \mathrm{ml}$ of diluent in a 

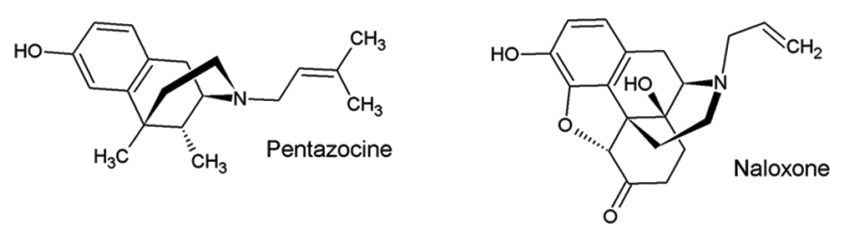

Fig. 1: Structures of drugs selected

$100 \mathrm{ml}$ standard flask to get a stock solution $(1000 \mu \mathrm{g} / \mathrm{ml}$ of pentazocine and $10 \mu \mathrm{g} / \mathrm{ml}$ of naloxone). This mixed stock solution was diluted aptly to get working solution with concentration $200 \mu \mathrm{g} / \mathrm{ml}$ of pentazocine and $2.0 \mu \mathrm{g} / \mathrm{ml}$ of naloxone with mobile phase.

\section{Calibration plot}

Calibration solutions with five different concentrations (pentazocine $100,150,200,250$, and $300 \mu \mathrm{g} / \mathrm{ml}$; and naloxone - 1.0, 1.5, 2.0, 2.5, and $3.0 \mu \mathrm{g} / \mathrm{ml}$ ) were prepared from mixed stock solution by apt dilution with diluent. These solutions were analyzed using the conditions given above (section - "chromatography conditions"). The calibration plot for pentazocine and naloxone was constructed separately by plotting the peak areas against the concentrations. The method's linearity was evaluated by determining the regression coefficient $\left(\mathrm{R}^{2}\right)$. Pentazocine and naloxone content in unknown samples were computed by referencing them to their respective calibration plots.

\section{Tablet analysis}

Pentazocine and naloxone combination tablets were grinded into powder. An appropriate weight of tablet powder equal to $200 \mathrm{mg}$ of pentazocine and $2 \mathrm{mg}$ of naloxone was taken, dissolved in $30 \mathrm{ml}$ of mobile phase and sonicated for $20 \mathrm{~min}$. The volume was then completed to $100 \mathrm{ml}$ with mobile phase $(2000 \mu \mathrm{g} / \mathrm{ml}$ of pentazocine and $20 \mu \mathrm{g} / \mathrm{ml}$ of naloxone). One $\mathrm{ml}$ of prepared solution was diluted with diluent to $10 \mathrm{ml}$ ( $200 \mu \mathrm{g} / \mathrm{ml}$ of pentazocine and $2 \mu \mathrm{g} / \mathrm{ml}$ of naloxone) for analysis by the proposed method. Pentazocine and naloxone contents in the tablets were computed by referencing them to their respective calibration plots.

\section{Stress-induced degradation}

The stress conditions used to induce degradation are as follows [29]:

- Neutral hydrolysis

- Base hydrolysis

- Acid hydrolysis

- Oxidation

- Thermal

- Photolytic.

The degradation was performed by adding $10 \mathrm{ml}$ of reagent to $10 \mathrm{ml}$ of tablet solution $(2000 \mu \mathrm{g} / \mathrm{ml}$ pentazocine and $20 \mu \mathrm{g} / \mathrm{ml}$ naloxone). Hydrochloric acid $(0.1 \mathrm{~N})$, sodium hydroxide $(0.1 \mathrm{~N})$, deionized water, and hydrogen peroxide (30\%) were used as reagent for acid hydrolysis, base hydrolysis, neutral hydrolysis, and oxidation, respectively. The solutions were sonicated at $25 \pm 2^{\circ} \mathrm{C}$ for $30 \mathrm{~min}$. The samples were transmitted to a volumetric flask $(100 \mathrm{ml})$ and filled with diluent to $100 \mathrm{ml}$. Following degradation, samples are filtered with a membrane filter of $0.45 \mu \mathrm{m}$ pore size. Thermal stress was accomplished by exposing tablet powder (200 mg pentazocine and $2 \mathrm{mg}$ naloxone) to $105^{\circ} \mathrm{C}$ for $6 \mathrm{~h}$. Photolytic stress was accomplished by exposing tablet powder $(200 \mathrm{mg}$ pentazocine and $2 \mathrm{mg}$ naloxone) to sunlight for $24 \mathrm{~h}$. The thermal and photo degraded tablet sample solution was prepared as described earlier (section - "tablet analysis") and filtered with a membrane filter of $0.45 \mu \mathrm{m}$ pore size. The suggested HPLC method was then used to analyze each sample. The peak purity of pentazocine and naloxone in stressed samples was evaluated by the photodiode array detector.

\section{RESULTS AND DISCUSSION}

Method development

Different combinations of methanol and buffer $(0.1 \%$ phosphoric acid buffer, $0.1 \mathrm{M} \mathrm{Na}{ }_{2} \mathrm{HPO}_{4}$ buffer, and $0.1 \mathrm{M} \mathrm{K}_{2} \mathrm{HPO}_{4}$ buffer) with different
$\mathrm{pH}$, as well as different flow rates, were tested. Different C18 stationary phases (Waters, Develosil, Sunniest, and Dionex) with dimension $250 \mathrm{~mm} \times 4.6 \mathrm{~mm}$ and $5 \mu \mathrm{m}$ particle size were tested. Best peak width, peak symmetry, resolution, and sensitivity were obtained with Dionex C18 column, mobile phase mixture with $0.1 \mathrm{M} \mathrm{K}_{2} \mathrm{HPO}_{4}$ buffer ( $\mathrm{pH} 4.0$ ), and methanol in the ratio of 60:40 $(v / v)$. The optimized flow rate was $1.0 \mathrm{ml} / \mathrm{min}$ and detection wavelength was $248 \mathrm{~nm}$. The optimized conditions showed a rapid and good separation of pentazocine and naloxone with retention time $3.714 \mathrm{~min}-4.761 \mathrm{~min}$, respectively (Fig. 2).

\section{Method validation}

Method validation was carried out as per the ICH regulations [30,31].

\section{Selectivity}

During selectivity check, diluent blank, placebo, and tablet sample solution were screened and compared with standard solution for interference at retention times of pentazocine and naloxone. Significant interference was not observed at retention times of pentazocine and naloxone in the chromatograms of diluent blank, placebo, and tablet sample solution (Fig. 3). Thus, selectivity was demonstrated.

\section{System suitability}

The parameters regarding system suitability were tested by analysis $(n=5)$ of pentazocine and naloxone standard solution at a concentration of $200 \mu \mathrm{g} / \mathrm{ml}$ and $2 \mu \mathrm{g} / \mathrm{ml}$, respectively. The results were found within the acceptance criteria in line with ICH directives (Table 1).

\section{Linearity}

Linearity of pentazocine and naloxone was achieved over the range of $100-300 \mu \mathrm{g} / \mathrm{ml}$ and $1-3 \mu \mathrm{g} / \mathrm{ml}$, respectively. Linear regression equation and regression coefficient were calculated and given below:

- Pentazocine: Peak area=76697 $x-12761$, regression coefficient, $\mathrm{R}^{2}=0.9999$

- Naloxone: Peak area=14621 $x-246.8$, regression coefficient, $\mathrm{R}^{2}=0.9995$.

The good linearity of the method for pentazocine and naloxone was demonstrated through regression coefficient values (>0.999).

\section{Limit of detection (LOD) and limit of quantitation (LOQ)}

LOD and LOQ were assessed based on the standard deviation (SD) of intercept and slope (m) of the calibration plot. The below equations were employed to compute the LOD and LOQ values.

$$
\begin{aligned}
& \mathrm{LOD}=\mathrm{SD} / \mathrm{m} \times 3.3 \\
& \mathrm{LOQ}=\mathrm{SD} / \mathrm{m} \times 10
\end{aligned}
$$

The LOD and LOQ were $0.097 \mu \mathrm{g} / \mathrm{ml}$ and $0.322 \mu \mathrm{g} / \mathrm{ml}$ for pentazocine and $0.0073 \mu \mathrm{g} / \mathrm{ml}$ and $0.0243 \mu \mathrm{g} / \mathrm{ml}$ for naloxone, respectively. Values lesser than $1 \mu \mathrm{g} / \mathrm{ml}$ confirm that the developed method was sensitive adequately.

\section{Precision}

The precision was appraised by analyzing $(\mathrm{n}=6)$ pentazocine and naloxone standard solution at a concentration of $200 \mu \mathrm{g} / \mathrm{ml}$ and $2 \mu \mathrm{g} / \mathrm{ml}$, respectively, on the same day [31,32]. The mean peak area along with the relative SD was determined (Table 2). The results were found to be within the acceptance criteria (percent relative standard deviation $[\mathrm{RSD}]$ value $-<2.0 \%$ ).

\section{Accuracy}

The accuracy was appraised by recovery study through standard addition method $[32,33]$. The percent recovery studies for pentazocine and naloxone were done by spiking three different amounts of pentazocine and naloxone standard $(50,100$, and $150 \%)$ to the pre-analyzed tablet sample. The percent recovery of pentazocine and naloxone was determined in three replicates for each level (Tables 3 and 4). The results of percent recovery were found within the acceptance criteria $(80-120 \%)$. 


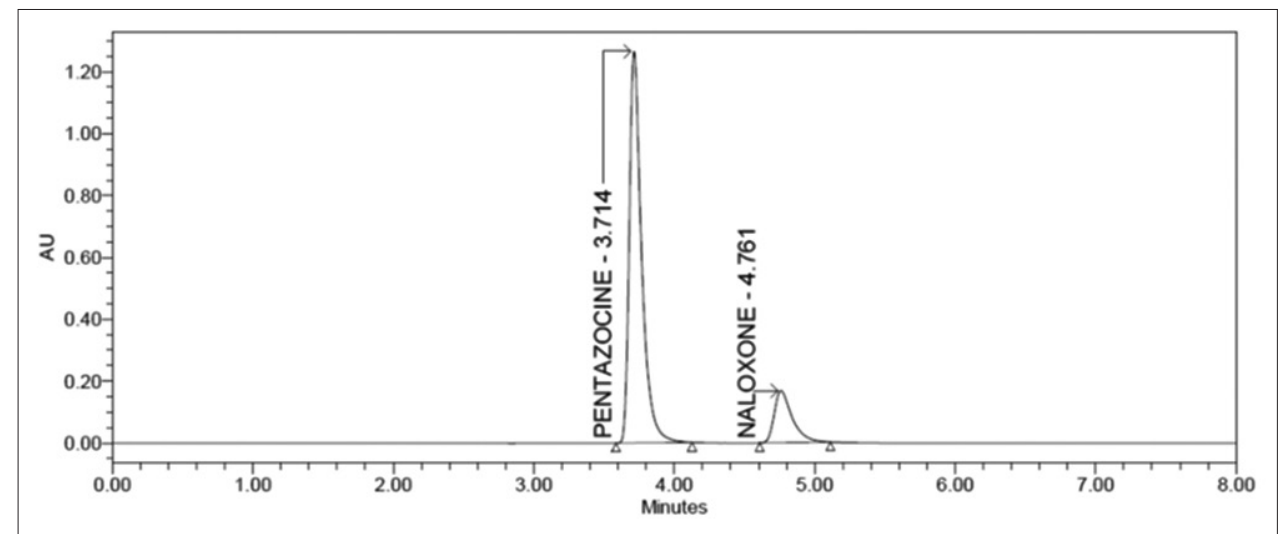

Fig. 2: Chromatogram of pentazocine and naloxone with optimized conditions
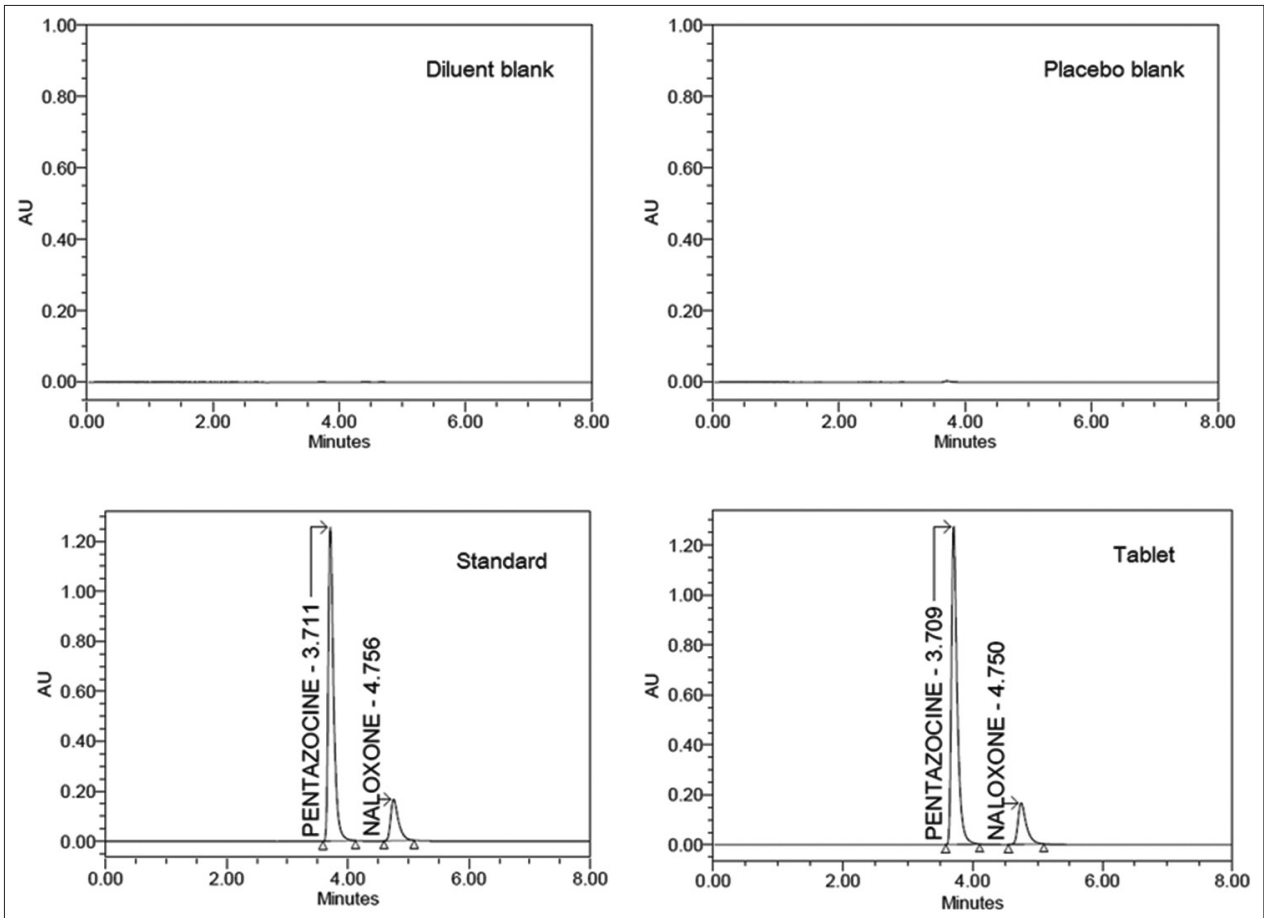

Fig. 3: Chromatograms proving selectivity

Table 1: System suitability data for pentazocine and naloxone

\begin{tabular}{|c|c|c|c|c|c|}
\hline $\begin{array}{l}\text { Statistical } \\
\text { parameter }\end{array}$ & Retention time & Area & Plate count & Tailing factor & Resolution \\
\hline \multicolumn{6}{|l|}{ Pentazocine } \\
\hline Mean* & 3.712 & 7655800 & 9203 & 1.166 & - \\
\hline $\mathrm{SD}^{* *}$ & 0.0011 & 37675.9570 & 211.7114 & 0.0089 & - \\
\hline $\mathrm{RSD}^{* * *}$ & 0.031 & 0.492 & 2.301 & 0.767 & - \\
\hline Criteria limits [30] & $\mathrm{RSD}-\leq 2 \%$ & $\mathrm{RSD}-\leq 2 \%$ & $>2000$ & $\leq 2.0$ & $\leq 2.0$ \\
\hline \multicolumn{6}{|l|}{ Naloxone } \\
\hline Mean* & 4.757 & 1466529 & 7063 & 5.246 & 1.268 \\
\hline $\mathrm{SD}^{* *}$ & 0.0014 & 6299.2275 & 140.7434 & 0.0594 & 0.0083 \\
\hline $\mathrm{RSD}^{* * *}$ & 0.030 & 0.430 & 1.993 & 1.133 & 0.660 \\
\hline Criteria limits [30] & $\mathrm{RSD}-\leq 2 \%$ & $\mathrm{RSD}-\leq 2 \%$ & $>2000$ & $\leq 2.0$ & $\leq 2.0$ \\
\hline
\end{tabular}

${ }^{*}$ Mean of five determinations, ${ }^{* *}$ standard deviation, ${ }^{* * *}$ relative standard deviation

\section{Robustness}

Five variation parameters were studied to demonstrate robustness:

- Change in ratio of methanol by $\pm 5.0 \%$

- Change in $\mathrm{pH}$ of buffer by \pm 0.1 unit

- $\quad$ Change in flow rate by $\pm 0.1 \mathrm{ml} / \mathrm{min}$
- $\quad$ Change in detection wavelength by $\pm 2 \mathrm{~nm}$

- Change in column temperature by $\pm 2.0^{\circ} \mathrm{C}$.

The peak area, plate count, resolution, and tailing factor values of pentazocine and naloxone obtained from variation parameters were 


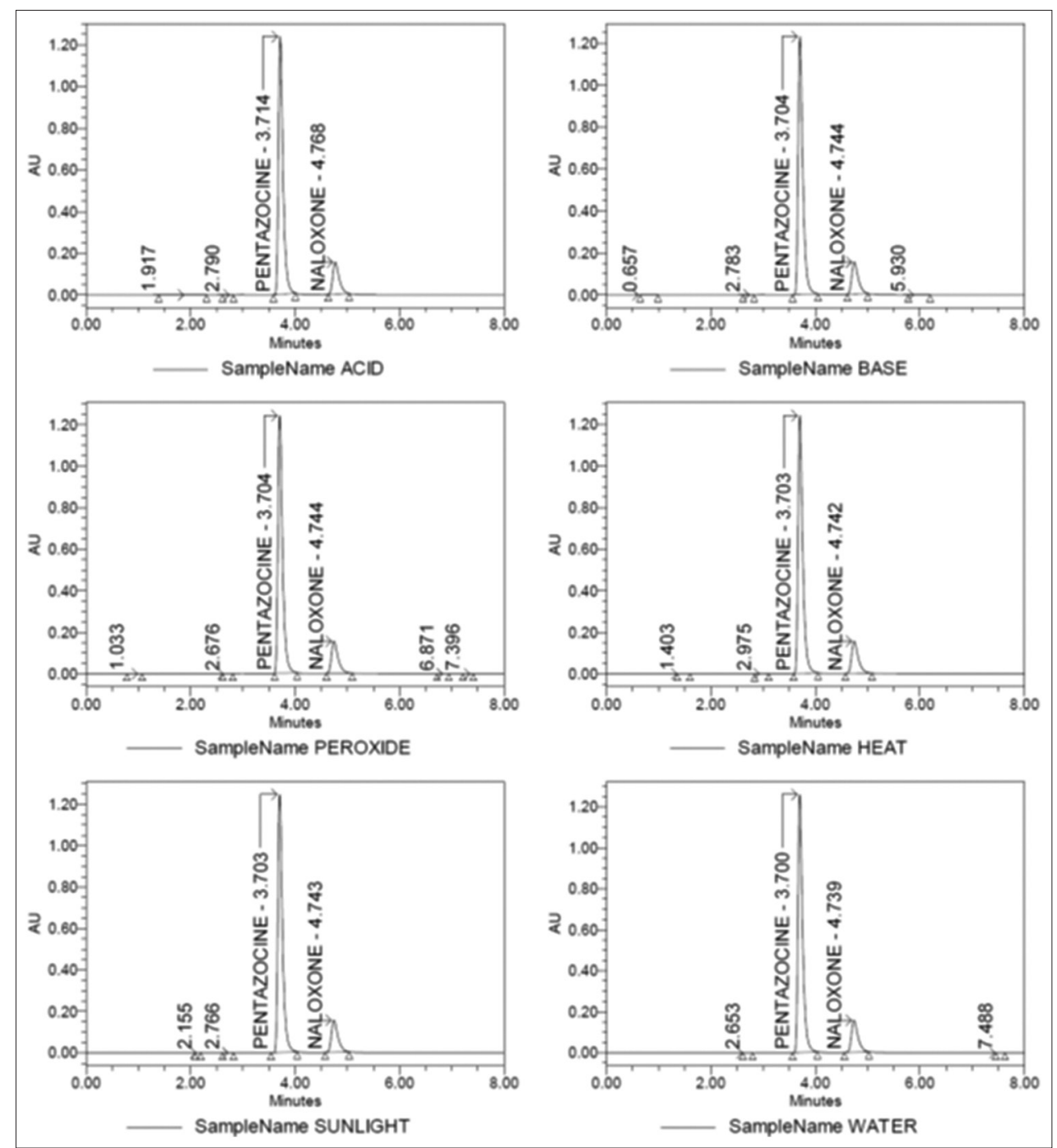

Fig. 4: Chromatograms proving stability indicating and specificity

Table 2: Precision data for pentazocine and naloxone

\begin{tabular}{|c|c|c|}
\hline \multirow[t]{2}{*}{ Inj. No.* } & \multicolumn{2}{|l|}{ Peak area } \\
\hline & Pentazocine & Naloxone \\
\hline 1 & 7641945 & 1464317 \\
\hline 2 & 7655208 & 1451732 \\
\hline 3 & 7644772 & 1462000 \\
\hline 4 & 7646482 & 1463570 \\
\hline 5 & 7641857 & 1451692 \\
\hline 6 & 7653061 & 1450658 \\
\hline Mean** & 7647221 & 1457328 \\
\hline $\mathrm{SD}^{* * *}$ & 5675.3883 & 6590.9768 \\
\hline RSD**** & 0.074 & 0.452 \\
\hline
\end{tabular}

*Injection number, ${ }^{* *}$ mean of five determinations, ${ }^{* * *}$ standard deviation $* * * *$ relative standard deviation

compared with the acceptance limits. The results were within the acceptance criteria (Table 5).

\section{Degradation study}

Degradation investigation outcomes are shown in Table 6. Degradation of pentazocine and naloxone was seen in the stress conditions applied. Highest degradation of pentazocine and naloxone was observed in dry heat and acid conditions applied. Lowest degradation of pentazocine and naloxone was observed with neutral and peroxide conditions applied. The chromatograms of pentazocine and naloxone after degradation
Table 3: Recovery data for pentazocine

\begin{tabular}{|c|c|c|c|c|}
\hline \multirow{2}{*}{$\begin{array}{l}\text { Level } \\
\text { spiked (\%) }\end{array}$} & \multicolumn{2}{|c|}{ Amount $(\mu \mathrm{g} / \mathrm{ml})$} & \multirow{2}{*}{$\begin{array}{l}\text { Recovery } \\
(\%)\end{array}$} & \multirow{2}{*}{$\begin{array}{l}\text { Mean* } \\
(\%)\end{array}$} \\
\hline & Spiked & Determined & & \\
\hline \multirow[t]{3}{*}{50} & 99.000 & 99.31 & 100.31 & \multirow[t]{3}{*}{100.28} \\
\hline & 99.000 & 99.20 & 100.20 & \\
\hline & 99.000 & 99.32 & 100.32 & \\
\hline \multirow[t]{3}{*}{100} & 198.000 & 198.86 & 100.43 & \multirow[t]{3}{*}{100.42} \\
\hline & 198.000 & 198.87 & 100.44 & \\
\hline & 198.000 & 198.77 & 100.39 & \\
\hline \multirow[t]{3}{*}{150} & 297.000 & 296.99 & 100.00 & \multirow[t]{3}{*}{100.12} \\
\hline & 297.000 & 298.62 & 100.54 & \\
\hline & 297.000 & 296.44 & 99.81 & \\
\hline
\end{tabular}

*Mean of three determinations

are presented in Fig. 4. The times of elution of pentazocine, naloxone, and degradants are different. These findings proved that the method is stability indicating and specific.

Tablet analysis

The method was applied to evaluate the content of pentazocine and naloxone in tablets. The recovered values were $100.237 \%$ for pentazocine and $101.013 \%$ for naloxone, indicating the method's reliability (Table 7 ). The RSD values were $0.150 \%$ for pentazocine and $0.178 \%$ for naloxone (Table 7 ), indicating the method's reproducibility. 
Table 4: Recovery data for naloxone

\begin{tabular}{|c|c|c|c|c|}
\hline \multirow{2}{*}{$\begin{array}{l}\text { Level } \\
\text { spiked (\%) }\end{array}$} & \multicolumn{2}{|c|}{ Amount $(\mu \mathrm{g} / \mathrm{ml})$} & \multirow{2}{*}{$\begin{array}{l}\text { Recovery } \\
\text { (\%) }\end{array}$} & \multirow{2}{*}{$\begin{array}{l}\text { Mean* } \\
\text { (\%) }\end{array}$} \\
\hline & Spiked & Determined & & \\
\hline \multirow[t]{3}{*}{50} & 0.980 & 0.99 & 101.15 & \multirow[t]{3}{*}{101.15} \\
\hline & 0.980 & 0.99 & 101.16 & \\
\hline & 0.980 & 0.99 & 101.14 & \\
\hline \multirow[t]{3}{*}{100} & 1.960 & 1.98 & 101.14 & \multirow[t]{3}{*}{101.08} \\
\hline & 1.960 & 1.99 & 101.31 & \\
\hline & 1.960 & 1.98 & 100.78 & \\
\hline \multirow[t]{3}{*}{150} & 2.940 & 2.96 & 100.75 & \multirow[t]{3}{*}{100.81} \\
\hline & 2.940 & 2.97 & 100.90 & \\
\hline & 2.940 & 2.96 & 100.78 & \\
\hline
\end{tabular}

*Mean of three determinations

Table 5: Robustness data for pentazocine and naloxone

\begin{tabular}{|c|c|c|c|c|c|c|c|c|}
\hline \multirow{2}{*}{$\begin{array}{l}\text { Parameter } \\
\text { Drug }\end{array}$} & \multicolumn{2}{|c|}{ Retention time } & \multicolumn{2}{|c|}{ Plate count } & \multicolumn{2}{|c|}{ Tailing factor } & \multicolumn{2}{|c|}{ Resolution } \\
\hline & Pen & Nal & Pen & Nal & Pen & Nal & Pen & Nal \\
\hline Flow 1 & 3.086 & 3.952 & 8275 & 6661 & 1.13 & 1.22 & - & 5.05 \\
\hline Temp 1 & 4.092 & 5.227 & 9227 & 7425 & 1.11 & 1.25 & - & 5.25 \\
\hline Temp 2 & 4.628 & 5.929 & 9482 & 7494 & 1.14 & 1.28 & - & 5.34 \\
\hline Ratio 1 & 3.086 & 3.952 & 8275 & 6661 & 1.13 & 1.22 & - & 5.05 \\
\hline Ratio 2 & 4.092 & 5.227 & 9227 & 7425 & 1.21 & 1.25 & - & 5.25 \\
\hline PH 1 & 3.712 & 4.755 & 9072 & 7006 & 1.18 & 1.27 & - & 5.20 \\
\hline PH 2 & 3.708 & 4.751 & 8951 & 6948 & 1.17 & 1.27 & - & 5.18 \\
\hline $\mathrm{Nm} 1$ & 3.714 & 4.758 & 9161 & 7013 & 1.17 & 1.29 & - & 5.22 \\
\hline $\mathrm{Nm} 2$ & 3.713 & 4.756 & 9557 & 7366 & 1.16 & 1.26 & - & 5.35 \\
\hline
\end{tabular}

Pen: Pentazocine, Nal: Naloxone, Flow 1: $0.9 \mathrm{ml} / \mathrm{min}$, Flow 2: $1.1 \mathrm{ml} / \mathrm{min}$, Temp 1: $23^{\circ} \mathrm{C}$, Temp 2: $27^{\circ} \mathrm{C}$, Ratio 1 : Methanol ration $45 \%$ by volume, Ratio $2:$ Methanol ratio $35 \%$ by volume, PH 1: 3.9 units, PH 2: 4.1 units, Nm 1: Wavelength $246 \mathrm{~nm}, \mathrm{Nm}$ 2: Wavelength $250 \mathrm{~nm}$

Table 6: Degradation data for pentazocine and naloxone

\begin{tabular}{lllllll}
\hline $\begin{array}{l}\text { Deg. } \\
\text { with }\end{array}$ & Pen area & Nal area & $\begin{array}{l}\text { Pen \% } \\
\text { assay }\end{array}$ & $\begin{array}{l}\text { Nal \% } \\
\text { assay }\end{array}$ & $\begin{array}{l}\text { Pen \% } \\
\text { deg }\end{array}$ & $\begin{array}{l}\text { Nal \% } \\
\text { deg }\end{array}$ \\
\hline Acid & 7243689 & 1334725 & 94.52 & 90.57 & 5.48 & 9.43 \\
Base & 7340455 & 1361014 & 95.79 & 92.35 & 4.21 & 7.65 \\
Peroxide & 7421869 & 1444737 & 96.85 & 98.04 & 3.15 & 1.96 \\
Heat & 7198634 & 1355646 & 93.93 & 91.99 & 6.07 & 8.01 \\
Sunlight & 7505340 & 1393436 & 97.94 & 94.55 & 2.06 & 5.45 \\
Water & 7530071 & 1438596 & 98.26 & 97.62 & 1.74 & 2.38 \\
\hline
\end{tabular}

Pen: Pentazocine, Nal: Naloxone, Deg: Degradation

Table 7: Quantification of pentazocine and naloxone in tablets

\begin{tabular}{clll}
\hline $\begin{array}{l}\text { Statistical } \\
\text { parameter }\end{array}$ & $\begin{array}{l}\text { Label } \\
\text { claim (mg) }\end{array}$ & Determined (mg) & Recovered (\%) \\
\hline $\begin{array}{l}\text { Pentazocine } \\
\text { Mean* }\end{array}$ & 50 & 50.137 & \\
SD** & - & 0.0750 & 100.273 \\
RSD*** & - & 0.150 & 0.1501 \\
Naloxone & & & 0.150 \\
Mean* & 0.5 & 0.505 & 101.013 \\
SD** & - & 0.0008 & 0.1795 \\
RSD*** & - & 0.178 & 0.178 \\
\hline
\end{tabular}

${ }^{*}$ Mean of three determinations, ${ }^{* *}$ standard deviation, ${ }^{* * *}$ relative standard deviation

\section{CONCLUSION}

A simple and rapid RP-HPLC method was developed to quantify pentazocine and naloxone in bulk and tablets. The results of validation are satisfactory and adequate to quantify pentazocine and naloxone simultaneously. The results of forced degradation studies established the specificity and stability indicating nature of the method. The method offers adequate selectivity and accuracy for routine evaluation and quality control in laboratories for pentazocine and naloxone.

\section{ACKNOWLEDGMENTS}

The authors are thankful to the management of GITAM University, Visakhapatnam, Andhra Pradesh, India, for providing necessary facilities to carry out the research work.

\section{AUTHORS' CONTRIBUTION}

This work was done by RKK under the supervision of RS.

\section{CONFLICTS OF INTEREST}

The authors declared that they have no conflicts of interest.

\section{REFERENCES}

1. Gasparre G, Abate C, Carlucci R, Berardi F, Cassano G. The $\sigma_{1}$ receptor agonist (+)-pentazocine increases store-operated $\mathrm{Ca}^{+}$entry in $\mathrm{MCF} 7 \sigma_{1}$ and SK-N-SH cell lines. Pharmacol Rep 2017;69:542-5.

2. Craft RM, McNiel DM. Agonist/antagonist properties of nalbuphine, butorphanol and (-)-pentazocine in male vs. Female rats. Pharmacol Biochem Behav 2003;75:235-45.

3. Hoskin PJ, Hanks GW. Opioid agonist-antagonist drugs in acute and chronic pain states. Drugs 1991;41:326-44.

4. Wang N, Wang L, Gao Y, Zhou H, Wang J. Analgesic effect of preoperative pentazocine for laparoscopic cholecystectomy. Cureus 2016;8:e948

5. Xu HQ, Xing JM, Jia R. Clinical observation of pentazocine for postoperative intravenous analgesia in patients with lumbar herniation. Zhongguo Gu Shang 2010;23:838-40.

6. Dhanalakshmi K. Opioid Analgesics. In: Pain Management. Vol. 2., Ch. 113. Netherlands: Elsevier Publications; 2007. p. 939-64.

7. Chimbar L, Moleta Y. Naloxone effectiveness: A systematic review. J Addict Nurs 2018;29:167-71.

8. van Dorp E, Yassen A, Dahan A. Naloxone treatment in opioid addiction: The risks and benefits. Expert Opin Drug Saf 2007;6:125-32. 
9. Lynn RR, Galinkin JL. Naloxone dosage for opioid reversal: Current evidence and clinical implications. Ther Adv Drug Saf 2018;9:63-88.

10. Connors NJ, Nelson LS. The evolution of recommended naloxone dosing for opioid overdose by medical specialty. J Med Toxicol 2016;12:276-81.

11. Elzey MJ, Fudin J, Edwards ES. Take-home naloxone treatment for opioid emergencies: A comparison of routes of administration and associated delivery systems. Expert Opin Drug Deliv 2017;14:1045-58.

12. FDA Approved Drug Products. Available from: https://www. accessdata.fda.gov/scripts/cder/daf/index.cfm? event $=$ overview. process \&ApplNo=074736. [Last accessed on 2019 Jun].

13. Pentazocine and Naloxone (Oral Route). Drugs and Supplements, Mayoclinic. Available from: https:/www.mayoclinic.org/drugssupplements/pentazocine-and-naloxone-oral-route/description/drg20074147. [Last accessed on 2019 Jun].

14. Pentazocine and Naloxone Pentazocine Hydrochloride and Naloxone Hydrochloride Tablet. Dailymed. Available from: https://dailymed. nlm.nih.gov/dailymed/drugInfo.cfm?setid=a28450a0-ac93-4235-b9a6$58 \mathrm{cdf} 24773 \mathrm{cb}$. [Last accessed on 2019 Jun].

15. Sastry CS, Rekha TV, Satyanarayana A. Spectrophotometric determination of pentazocine in pharmaceutical formulations. Indian J Pharma Sci 1998;60:55-8.

16. Revanasiddappa HD, Veena MA. A sensitive spectrophotometric determination of ritodrine, pentazocine, isoxsuprine hydrochlorides and amoxicillin in pure and pharmaceutical samples. E-J Chem 2008;5:100-6.

17. Poprzen V, Radulović D. UV-densitometry determination of pentazocine hydrochloride in tablets after low temperature extraction. Vojnosanit Pregl 2001;58:267-71.

18. Kelly JW, Stewart JT, Blanton CD. HPLC separation of pentazocine enantiomers in serum using an ovomucoid chiral stationary phase. Biomed Chromatogr 1994;8:255-7.

19. Hiedaki M, Kengo O, Ken-Ich H, Makoto S, Kazuhiro I, Hideo N, et al. Quantification of pentazocine in human plasma by HPLC with electrochemical detection. J Liquid Chromatogr 1992;15:3247-60.

20. Moeller N, Dietzel K, Nuernberg B, Geisslinger G, Brune K. Highperformance liquid chromatographic determination of pentazocine in plasma. J Chromatogr 1990;530:200-5.

21. Ali RA, Ali AE, Saraji M. Rapid determination of pentazocine in human plasma and urine by a potentiometric method. Anal Lett
2009; 42:571-83

22. Seno H, Kumazawa T, Ishii A, Matsushima H, Watanabe-Suzuki K, Suzuki O, et al. Determination of pentazocine in human whole blood and urine by gas chromatography/surface ionization organic mass spectrometry. J Mass Spectrom 2000;35:33-8

23. Gil-Alegre ME, Barone ML, Torres-Suárez AI. Extraction and determination by liquid chromatography and spectrophotometry of naloxone in microparticles for drug-addiction treatment. J Sep Sci 2005;28:2086-93.

24. Mostafa ST, Mohamed EM, Mahmoud MA. Determination of naloxone hydrochloride in dosage form by high-performance liquid chromatography. J Liquid Chromatogr 1983;6:1491-97.

25. Panchagnula R, Sharma P, Khandavilli S, Varma MV. RP-HPLC method and its validation for the determination of naloxone from a novel transdermal formulation. Farmaco 2004;59:839-42.

26. Reid RW, Deakin A, Leehey DJ. Measurement of naloxone in plasma using high-performance liquid chromatography with electrochemical detection. J Chromatogr 1993;614:117-22.

27. Franklin M, Odontiadis J. Determination of naloxone in human plasma by high-performance liquid chromatography with coulometric detection. J Chromatogr B Biomed Appl 1996;679:199-203.

28. Fang WB, Chang Y, McCance-Katz EF, Moody DE. Determination of naloxone and nornaloxone (noroxymorphone) by high-performance liquid chromatography-electrospray ionization- tandem mass spectrometry. J Anal Toxicol 2009;33:409-17.

29. International Conference on Harmonization, Stability Testing of New Drug Substances and Products (Q1AR2). Geneva, Switzerland: Proceedings of the International Conference on Harmonization; 2003.

30. International Conference on Harmonization of Technical Requirements for Registration of Pharmaceuticals for Human Use, ICH Harmonized Tripartite Guideline. Validation of Analytical Procedures: Text and Methodology Q2 (R1). Geneva, Switzerland: ICH; 2005.

31. Sharma S, Goyal S, Chauhan K. A review on analytical method development and validation. Int J Appl Pharm 2018;10:8-15.

32. Hemant KJ, Umakant SJ. Development and validation of RP-HPLC method for estimation of darunavir ethanolate in bulk and tablets. Int $\mathrm{J}$ Pharm Pharm Sci 2015;7:386-9.

33. Babu GR, Rao AL, Rao JV. A rapid RP-HPLC method development and validation for the quantitative estimation ribavirin in tablets. Int $\mathrm{J}$ Pharm Pharm Sci 2015;7:60-3. 